\title{
PERAN ORANG TUA DALAM PEMBELAJARAN DARING ANAK BERKEBUTUHAN KHUSUS PADA MASA PANDEMI COVID-19 DI SEKOLAH INKLUSI SDN MOJOREJO I KOTA BATU
}

\author{
Saraswati Arsani ${ }^{1}$, Nur Hadi², Joan Hesti Gita Purwasih ${ }^{3}$ \\ 'Prodi Pendidikan Sosiologi, Universitas Negeri Malang, \\ Correspondence email: saraswatiarsani@gmail.com \\ ${ }^{2}$ Prodi Pendidikan Sosiologi, Universitas Negeri Malang, \\ Correspondence email: nur.hadi.fis@um.ac.id \\ 3Prodi Pendidikan Sosiologi, Universitas Negeri Malang, \\ Correspondence email: joan.hesti.fis@um.ac.id
}

\begin{abstract}
Learning from home for all students is a way to break transmission Covid-19, no exception for disability students. The roles parents to accompanying their child is very important. This study aims to describe the implanting home base learning and the role parents for helping the child with special needed. This research uses qualitative descriptive by interviewing at home. The role parents can be replaced with private teacher for helpin and, accompany their child with special needed.
\end{abstract}

Keywork:

Home base learning, child with special needed, the role parents, Covid-19

\begin{abstract}
Abstrak
Belajar dari rumah merupakan cara memutus penularan Covid-19, untuk semua siswa tidak terkecuali anak berkebutuhan khusus. Peran orang tua dalam mendampingi siswa dalam pembelajaran daring sangat diperlukan untuk anak berkebutuhan khusus. Penelitian ini bertujuan mendeskripsikan tentang penerapan pembelajaran daring dan peran orang tua dalam membantu siswa terutama bagi anak berkebutuhan khusus. Penelitian ini menggunakan metode kualitatif deskriptif dengan wawancara di rumah. Peran orang tua dalam mendampingi anak berkebutuhan khusus dapat digantikan dengan guru privat yang dipercaya mampu mendampingi anak berkebutuhan khusus pada saat pembelajaran daring.
\end{abstract}

Kata Kunci:

Pembelajaran daring, Anak berkebutuhan khusus, Peran orang tua, Covid-19

\section{A. PENDAHULUAN}

Keberadaan anak berkebutuhan khusus (ABK) dimasyarakat dianggap sebelah mata dan perlu dikasihani, hal tersebut menyebabkan anak berkebutuhan khusus (ABK) sering dikucilkan atau termaginalkan dilingkungan sekitarnya. Selain itu anak berkebutuhan khusus (ABK) sering menerima perlakukan diskriminatif dari orang lain bahkan dalam memperoleh pendidikanpun mereka kesulitan. Banyak sekolah reguler yang tidak mau menerima anak berkebutuhan khusus (ABK) dikarenakan sekolah tidak memiliki fasilitas yang memadai untuk mendukung keberadaan anak berkebutuhan khusus (ABK). Untuk mengatasi permasalahan tersebut sesuai dengan kebijakan pemerintah yang tertuang pada Undang-Undang Nomor 20 tahun 2003 pada pasal 32 dan Permendiknas nomor 70 tahun 2009 yaitu dengan memberikan peluang dan 
kesempatan kepada anak berkebutuhan khusus untuk memperoleh pendidikan disekolahan reguler dan juga pada UUD 1945 BAB IV Pasal 2, 3, dan 4 menegaskan bahwa anak berkebutuhan khusus memperoleh pendidikan layanan khusus. Anak berkebutuhan khusus disini bukan hanya mereka yang memiliki kelainan fisik, sosial, emosional dan intelektual saja, melainkan mereka yang memiliki potensi kecerdasaan dan bakat istimewa juga berhak memperoleh pendidikan layanan khusus. Berdasarkan kebijakan tersebut didirikan sekolah inklusi. Menurut (Ilahi, 2013) sekolah inklusi adalah sekolah reguler yang disesuaikan dengan kebutuhan anak yang memiliki kelainan dan memiliki potensi kecerdasan dan bakat istimewa pada satu kesatuan yang sistematis. Sekolah inklusi diselenggarakan sebagai bentuk fasilitas pendidikan bagi anak berkebutuhan khusus untuk memperoleh hak dan kewajiban yang sama dengan siswa reguler. Anak berkebutuhan khusus tidak mendapatkan keistimewaan melainkan diikutsertakan dalam proses pembelajaran bersama siswa normal dan diperlakukan selayaknya siswa normal lainnya. Sekolah inklusi diharapkan dapat memberikan dampak positif terhadap perkembangan anak berkebutuhan khusus dari segi psikologis dan menghilangkan diskriminasi yang dialami anak berkebutuhan khusus (Pertiwi,2015).

Kementerian Pendidikan dan Kebudayaan menyebutkan berdasarkan data dari Badan Pusat Statistik jumlah anak berkebutuhan khusus (ABK) di Indonesia mencapai angka 1,6 juta anak, hanya 18 persen yang sudah mendapatkan layanan pendidikan inklusi. Sekitar 115 ribu anak berkebutuhan khusus (ABK) yang bersekolah di SLB, sedangkan anak berkebutuhan khusus (ABK) yang bersekolah disekolah reguler yang menjadi sekolah inklusi berjumlah sekitar 299 ribu anak. Saat ini terdapat 32 ribu sekolah inklusi diberbagai daerah diantaranya Kota Batu. Dinas Pendidikan Kota Batu pada tahun 2018 menyebutkan bahwa kota malang sebagai Kota Pendidikan Inklusi, yakni telah menyediakan sekolah inklusi bagi anak berkebutuhan khusus. Salah satunya SD Negeri Mojorejo I, sekolah tersebut menerima pendaftaran anak berkebutuhan khusus dengan kriteria ringan hingga sedang. Sarana dan prasarana mendukung proses pembelajaran anak berkebutuhan khusus, diantaranya kurikulum yang fleksibel atau adaptif, media pembelajaran yang menunjang anak berkebutuhan khusus (ABK), guru pembimbing khusus (GPK) atau guru kelas inklusi dan lingkungan sekolah yang aksesibel.

Penyebaran virus Covid-19 meningkat pesat di Indonesia akibatnya mempengaruhi berbagai bidang kehidupan, mulai dari bidang ekonomi, sosial, budaya dan pendidikan. Sebagai bentuk pencegahan pemerintah Indonesia berupaya untuk menekan penyebaran Covid-19 dengan mengeluarkan kebijakan PSBB berdasarkan Peraturan Pemerintah (PP) Nomor 21 Tahun 2020 dan Keputusan Presiden (Keppres) Nomor 11 Tahun 2020. Kebijakan PSBB merupakan pembatasan sosial berskala besar pada kegiatan masyarakat di suatu daerah atau kota. PSBB meliputi peliburan sekolah dan tempat kerja, pembatasan kegiatan 
keagamaan dan pembatasan kegiatan di tempat umum. Menanggapi kondisi tersebut Menteri Pendidikan menerbitkan Surat Edaran nomor 36962/MPK.A/HK/2020 tentang pembelajaran yang dilakukan secara daring sebagai upaya pencegahan penyebaran Covid-19. Melalui kebijakan tersebut maka pembelajaran disekolah ditiadakan dan dialihkan menjadi pembejaran jarak jauh atau yang sering disebut daring. Pembelajaran jarak jauh (PJJ) atau daring memanfaatkan teknologi berbasis internet sebagai media dan sumber belajar siswa. Pada masa pandemi saat ini menjadi tantangan tersendiri dalam melaksanakan pembelajaran jarak jauh pada siswa berkebutuhan khusus. Adanya perubahan sistem pembelajaran pada masa pandemi Covid-19 berpengaruh pada peranan orang tua dalam mendampingi siswa berkebutuhan khusus ketika pembelajaran daring dilakukan. Sebelumnya adanya perubahan sistem pembelajaran orang tua tidak banyak waktu dalam mendampingi dan membimbing anaknya, namun saat ini situasinya telah berubah orang tua diharuskan dapat membimbing anaknya dalam pembelajaran online dari rumah.

Penelitian sebelumnya telah banyak dilakukan mengenai peran orang tua dalam mendampingi anak di masa pandemi Covid-19. Kurniawati, (2020) menyatakan bahwa peran orang tua dalam masa pandemi Covid-19 adalah menjaga, mendampingi, membimbing, memotivasi dan memberikan edukasi. Sedangkan menurut Cahyani, (2020) orang tua berperan mendampingi proses pembelajaran daring yang dilakukan sehingga dapat mempererat hubungan orang tua dengan anak dan orang tua dapat melihat perkembangan anaknya ketika belajar dirumah. Melalui paparan tersebut orang tua berperan penting dalam mendampingi dan membimbing anak pada proses pembelajaran daring. Lalu bagaimana dengan wali murid dari anak berkebutuhan khusus ? Kemudian penelitian terdahulu secara spesifik mengenai peran orang tua dalam pendidikan anak berkebutuhan khusus. Darmono, (2015) mengatakan bahwa peran orang tua dalam pendidikan anak berkebutuhan khusus sangatlah vital, mereka paham akan pertumbuhan dan perkembangan anak sejak dilahirkan, hal tersebut dapat digunakan sebagai upaya mempersiapkan program pendidikan yang tepat bagi anak berkebutuhan khusus. Sejalan dengan hal tersebut, Amin (2015) mengungkapkan bahwa peran orang tua sebagai fasilitator untuk mencapai keberhasilan dalam pendidikan anak berkebutuhan khusus, selain itu diperlukan kerja sama antara orang tua dan guru untuk menciptakan pendidikan yang lebih baik dan bermakna. Oleh karena itu penelitian ini menjadi sangat penting dilakukan untuk memahami bagaimana penerapan dan peran orang tua anak berkebutuhan khusus dalam mendampingi proses pembelajaran daring pada masa pandemi Covid-19.

Penelitian ini menggunakan pendekatan deskriptif kualitatif yaitu penelitian tentang riset yang bersifat deskriptif dan cenderung menggunakan analisis. Peneliti menggunakan metode studi kasus, yakni desain penelitian yang digunakan untuk mengungkap secara lebih rinci dan komprehensif mengenai objek yang dianalisis (Alwasilah, 2002). Yin, (2003) menyatakan bahwa studi 
kasus sangat sesuai untuk menjawab pertanyaan- pertanyaan bagaimana, mengapa yang cenderung menjelaskan karena jenis pertanyaan seperti ini akan mengeksplorasi data lebih mendalam. Dalam hal ini penelitian menganalisis peran orang tua dalam pembelajaran daring anak berkebutuhan khusus (ABK) pada masa pandemi covid-19. Subjek dalam penelitian ini adalah orang tua anak berkebutuhan khusus dan guru pembina khusus (GPK) di SD Negeri Mojorejo I Kota Batu dengan jumlah 5 orang ( 4 walimurid dan 1 guru pembina khusus). Teknik pengumpulan data yang digunakan dengan wawancara dan data analisis dengaan menggunakan pengelompokan data, yaitu analisis dengan mengelompokan data sesuai dengan focus pedoman wawancara. Secara lebih rinci paparan alur penelitian dapat dilihat pada gambar 1 dibawah ini.

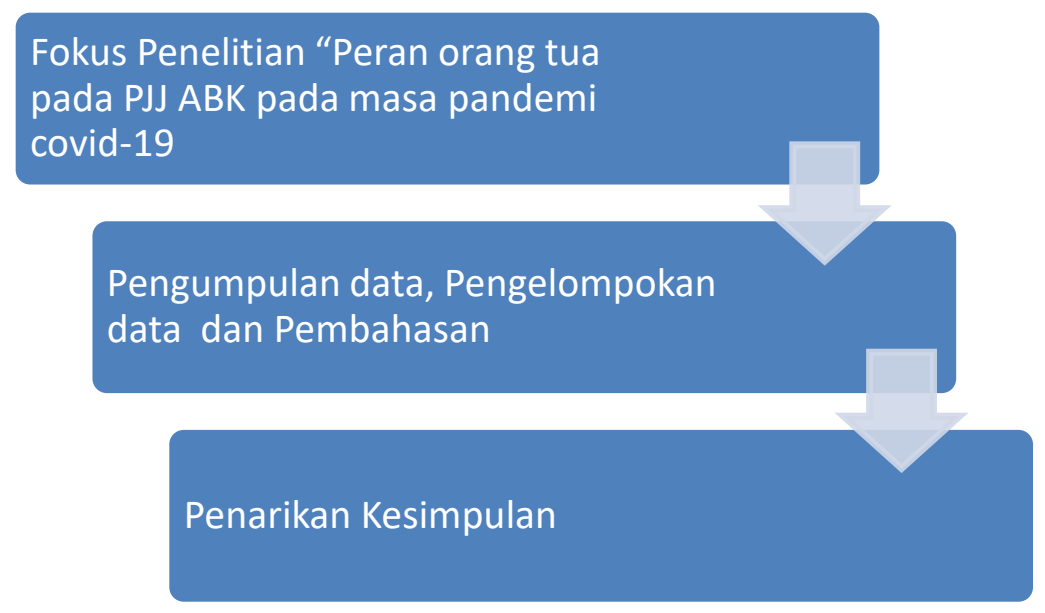

Gambar 1. Alur penelitian

\section{B. HASIL DAN PEMBAHASAN \\ 1. Pembelajaran daring pada anak berkebutuhan khusus.}

Sejak bulan Maret 2020 penyebaran virus Covid-19 terjadi begitu cepat sehingga peningkatan pasien positif Covid-19 di Indonesia meningkat pesat. Pemerintah melalui kementerian pendidikan dan kebudayaan berupaya melakukan pencegahan penularan Covid-19 dengan melaksanakan kegiatan pembelajaran jarak jauh atau daring mulai dari sekolah dasar hingga perguruan tinggi. Pembelajaran jarak jauh merupakan sistem pembalajaran yang mana siswa tetap melaksanakan kegiatan belajar seperti biasanya namun dilakukan dari rumah. Dalam pelaksanaannya guru dan tenaga pendidik lainnya memanfaatkan teknologi internet sebagai media dan sumber belajar siswa dirumah. Lalu bagaimana dengan kegiatan pembelajaran daring yang diterapkan kepada anak berkebutuhan khusus di sekolah inklusi ? Sekolah inklusi, Tarmansyah (2009) menyatakan bahwa sekolah inklusi merupakan sekolah yang menampung anak berkebutuhan khusus tingkat ringan, sedang dan berat secara penuh di kelas reguler. Sekolah inklusi memberikan kesempatan bagi siswa ABK 
untuk memperoleh pendidikan yang sama dengan siswa reguler, hal tersebut berdampak baik bagi perkembangan siswa ABK. Dalam prosesnya, pembelajaran daring yang diterapkan pada anak berkebutuhan khusus berbeda dengan anak reguler pada umumnya, anak berkebutuhan khusus terkendala dalam mengikuti pembelajaran daring yang berlangsung, hal ini disebabkan karena anak berkebutuhan khusus memiliki kemampuan dan kebutuhan yang berbeda-beda dan tidak bisa dipaksakan untuk dapat mengikuti pembelajaran daring yang dilakukan oleh siswa reguler. SDN Mojorejo I sebagai sekolah inklusi menyediakan sistem pembelajaran daring yang diperlukan untuk dapat melaksanakan pembelajaran daring pada anak berkebutuhan khusus. Hal ini sesuai dengan hasil wawancara dengan guru pembimbing khusus :

" Tentunya pembelajaran daring yang dilakukan untuk anak berkebutuhan khusus akan berbeda dengan anak regular. Hal ini berdasarkan kemampuan dan kebutuhan ABK yang berbeda-beda, kita sebagai pengajar tidak bisa memaksakan agar anak-anak berkebutuhan khusus ini dapat mengikuti pembelajaran daring seperti yang dilakukan siswa reguler"

Progam pembelajaran daring yang dirancang oleh sekolah untuk anak berkebutuhan khusus, yakni jurnal berbasis aktivitas. Jurnal Berbasis Aktifitas merupakan jurnal yang berisi tentang pemetaan kegiatan siswa seharihari selama pandemi, yang mencakup terapi, bina diri, literasi, numerasi dan refleksi. Tujuan dari program jurnal berbasis aktifitas ini adalah untuk memudahkan pemetaan kegiatan belajar anak berkebutuhan khusus selama pembelajaran daring selama pandemi. Melalui sistem pembelajaran ini anak berkebutuhan khusus di SDN Mojorejo I tetap dapat melakukan pembelajaran dirumah dan tidak tertinggal dengan siswa reguler.

2. Pelaksanaan pembelajaran daring anak berkebutuhan berkebutuhan khusus.

Kegiatan pembelajaran daring dilakukan setiap hari sesuai dengan RPP yang telah disusun oleh guru pembimbing khusus. Jurnal berbasis aktivitas telah digunakan sejak awal pandemi, hal ini berdasarkan hasil wawancara dengan guru pembimbing khusus di SD Negeri I Mojorejo Kota Batu

"Sejak awal pandemi jurnal berbasis aktifitas ini dilaksanakan mbak, karena memang tidak boleh dilakukan pembelajaran tatap muka dan sampai saat ini menginjak semester genap tahun ajaran 2020-2021 masih digunakan mbak".

Melalui jurnal berbasis aktivitas kegiatan pembelajaran daring pada anak berkebutuhan khusus dirancang untuk seminggu dan tugas dikumpulkan setiap hari. Sesuai dengan pernyataan guru pembimbing khusus bahwa :

"Pelaksanaan program jurnal berbasis aktifitas ini dirancang selama seminggu sekali dan tugas dikirimkan setiap hari sampai batas waktu 19.00 WIB. Kemudian guru membuat laporan hasil belajar siswa yang akan diberikan kepada kepala sekolah".

Dengan pembelajaran daring tersebut diharapkan siswa atau anak berkebutuhan khusus dapat mengikuti, memahami kegiatan pembelajaran yang dilakukan. 
3. Peran orang tua dalam mendampingi anak berkebutuhan khusus dalam pembelajaran daring.

Peran orang tua tidak lepas dari keluarga, keluarga merupakan kelompok sosial pertama dalam kehidupan sosial seorang anak yang dapat menentukan keberhasilan tumbuh kembang dan kemampuan masyarakat. Pada masa pandemi Covid-19 orang tua dituntut sebagai pendamping pendidikan akademik pada saat pembelajaran jarak jauh. Prabhawani (2016) mengatakan bahwa pelaksanaan pendidikan merupakan tanggung jawab orang tua dan masyarakat sekitar, tidak hanya tanggung jawab lembaga pendidikan saja. Hal ini berlaku sama dengan para orang tua anak berkebutuhan khusus, anak berkebutuhan khusus membutuhkan perhatian extra dalam membimbing, mendampingi dan mengarahkan pada kegiatan sehari-hari. Menurut Hewtt dan Frenk (1968) penanganan dan pelayanan orang tua terhadap anak berkebutuhan khusus adalah sebagai berikut :

a. Sebagai pendamping utama (as aids) yaitu sebagai pendamping utama yang dalam membantu tercapainya tujuan yakni pendidikan anak.

b. Sebagai advokat (as advocates) yang mengerti, mengusahakan, dan menjaga hak anak dalam kesempatan mendapat layanan pendidikan sesuai dengan karakteristik khususnya.

c. Sebagai sumber (as resources), menjadi sumber data yang lengkap dan benar mengenai diri anak dalam usaha intervensi perilaku anak.

d. Sebagai guru (as teacher), berperan sebagai pendidik bagi anak dalam kehidupan sehaıri-hari di luar jam sekolah.

e. Sebagai

(diagnosticians) menjadi penentu karakteristik dan jenis kebutuhan khusus dan berkemampuan melakukan treatmen, terutama diluar jam sekolah.

f. Kemudian Amin (2015) mengungkapkan bahwa peran orang tua sebagai fasilitator untuk mencapai keberhasilan dalam pendidikan anak berkebutuhan khusus, selain itu diperlukan kerja sama antara orang tua dan guru untuk menciptakan pendidikan yang lebih baik dan bermakna.

Dalam prosesnya ketersediaan waktu orang tua anak berkebutuhan khusus untuk mendampingi dan membimbing pada pembelajaran daring sangatlah terbatas. Pembelajaran daring yang dilakukan pada pagi hari harus tertunda dikarenakan orang tua yang harus bekerja, sedangkan anak berkebutuhan khusus membutuhkan pendamping sekaligus pembimbing yang dapat mengarahkan dalam pembelajaran daring. Akibatnya pembelajaran daring pada anak berkebutuhan khusus di SDN Mojorejo I Kota Batu terhambat dikarenakan para orang tua harus bekerja tidak bisa mendampingi siswa dalam pembelajaran daring. Upaya yang dilakukan orang tua dalam mengatasi hal tersebut adalah dengan menyediakan guru les privat agar dapat mendampingi anaknya dalam pembelajaran daring. Seperti yang disebutkan oleh salah satu walimurid dari anak berkebutuhan khusus:

"Karena saya kerja yah mbak jadi yang mendampingi mengerjakan jurnal berbasis aktifitasnya guru 
lesnya. Guru lesnya ini biasanya sore ngelesin sama terapi juga mbak, saya pasrahin ke guru lesnya mbak"

Hal tersebut dilakukan sebagai bentuk tanggung jawab dalam mendidik anaknya, terlebih dengan kondisi anak berkebutuhan khusus yang membutuhkan perhatian lebih dalam mendidiknya. Hubungan yang terjalin antara orang tua dengan anak tidak terjalin erat dikarenakan minimnya interaksi antara anak dan orang tua, hal ini akan berpengaruh pada tumbuh kembang anak terlebih lagi pada anak berkebutuhan khusus yang membutuhkan perhatian lebih. Salah satu peran orang tua adalah menjalin komunikasi yang baik dengan anak, Murtiningsih (2013) menjalin komunikasi yang dilakukan oleh orang tua dan anak menjadi penting karena hal tersebut dapat mempererat hubungan antara orang tua dan anak. Sedangkan menurut Bluth and Wahler (2011), dengan kegiatan seperti bercengkrama dengan anak-anak akan mendorong perilaku positif dan diharapkan hubungan yang terjalin pada saat melakukan hal tersebut dapat mencegah perilaku bermasalah serta sebagai cara membangun dan mempertahankan susasana keluarga positif. Oleh sebab itu orang tua diharuskan dapat menyediakan waktunya untuk mendampingi anaknya dalam pembelajaran daring, agar orang tua akan memahami perkembangan buah hatinya.

\section{Penelitian Terdahulu}

Penelitian terdahulu digunakan sebagai bahan pertimbangan dalam melakukan penelitian selanjutnya agar penelitian dapat terus berkembang. Melalui penelitian terdahulu peneliti meiliki referensi yang beragam mulai dari topik dan metode yang dapat digunakan untuk melakukan penelitian saat ini. Tujuan dari referensi penelitian terdahulu adalah untuk memberikan gambaran untuk penelitian selanjutnya yang memiliki relevansi, keterkaitan, hubungan dan kecocokan.

Penelitian terdahulu yang memiliki relevansi dengan penelitian yang akan diteliti, pertama penelitian dengan judul, Analisis Peran Orang Tua dalam Mendampingi Anak di Masa Pandemi Covid-19 oleh Euis Kurniawati Vol 5, No 1 (2021). Penelitian tersebut berfokus pada analisis peran orang tua dalam mendampingi kegiatan sehari-hari ketika dirumah pada masa pandemic covid-19. Penelitian tersebut menggunakan metode studi kasus dengan teknik wawancara narasumber. Tujuan dari penelitian tersebut adalah untuk memahami peran orang tua dan mengetahui hal-hal yang dilakukan dalam mendampingi anak pada masa pandemi covid-19.

Kedua, penelitian terdahulu oleh Adinda Cahyani (2020) yang berjudul Peran Orang Tua dalam Membimbing Anak Selama Pembelajaran di Rumah sebagai Upaya Memutus Covid-19. Penelitian tersebut mengangkat fenomena pandemi Covid-19 yang mengharuskan orang tua mendampingi anak dalam melakukan pembelajaran dirumah sebagai upaya memutus rantai penularan Covid-19. Penelitian tersebut menggunakan pendekatan kualitatif dengan metode diskriptif. Peran orang tua dalam proses pembelajaran dirumah sebagai upaya memutus rantai covid-19 menjadikan hubungan orang tua dengan anaknya semakin erat, anak dapat 
melakukan pembelajaran dirumah dengan baik.

Ketiga, penelitian yang berjudul Peran orang tua dalam pendidikan anak berkebutuhan khusus oleh Al Darmono (2015). Penelitian terssebut mengangkat tentang pendidikan inklusi sebagai pelaksana pendidikan anak berkebutuhan khusus dan peran orang tua yang memiliki anak berkebutuhan khusus yang bersekolah atau menempuh pendidikan di sekolah inklusi. Peranan orang tua diperlukan untuk pertumbuhan dan perkembangan anak berkebutuhan khusus.

Keempat, penelitian terdahulu dengan judul Peran Orang Tua dalam Pendidikan Inklusif (Peran Orang Tua Anak Berkebutuhan Khusus dalam Konteks Sekolah Inklusi) oleh Barkatullah Amin (2015). Pada penelitian tersebut membahas tentang bentuk kerjasama antara orang tua dan guru disekolah yang diperlukan untuk memberikan pendidikan yang tepat bagi anak berkeutuhan khusus. Penelitian tersebut menggunakan metode kualitatif dengan teknik wawancara mendalam kepada orang tua atau walimurid anak berkebutuhan khusus dan walikelas anak berkebutuhan khusus.

Penelitian ini menjadi penting dilakukan karena berfokus pada peran orang tua dalam mendampingi pembelajaran daring anak berkebutuhan khusus pada masa pandemic Covid-19. Pada penelitian ini peneliti menggunakan teori tindakan sosial dari pemikiran Talcott Parsons. Teori Parsons berfokus pada actor, pemikiran dan tindakan-tindakan actor yang menyeluruh menggunakan konsep tindakan sosial rasional. Dalam analisisnya, Parsons menggunakan kerangka alat tujuan (means ends framework) yang berisi:

a. Tindakan aktor diarahkan pada suatu tujuan atau bahwa setiap tindakan pasti memiliki tujuan.

b. Dalam tindakan terjadi suatu kondisi yang mana beberapa elemen didalamnya sudah pasti, sedangkan elemen-elemen lainnya digunakan oleh aktor sebagai alat untuk mencapai tujuan tersebut.

c. Tindakan tersebut dilihat sebagai suatu dari realitas sosial yang paling kecil dan fundamental. Elemen dasar dari tindakan adalah terdiri dari tujuan, alat, kondisi, nilai dan norma.

Secara lebih jelas bahwasannya aktor bertindak untuk mencapai tujuannya yang dipengaruhi oleh beragam factor diantaranya yakni ketersediaan alat (means), kondisi yang menghambat, nilai dan norma yang berlaku dilingkungannya, serta sistem budaya dimana aktor tersebut berada (Kingseng, 2017). Hasil penelitian ini menunjukkan tindakan yang diambil orang tua anak berkebutuhan khusus, memiliki tujuan yakni mengharapkan anaknya dapat melakukan pembelajaran dengan baik melalui support atau dukungan dari orang tua melalui atau penggunaan jasa guru privat. Guru privat memiliki menjadi sebuah alat untuk mencapai tujuan orang tua anak berkebutuhan khusus.

\section{KESIMPULAN}

Hasil Penelitian ini menunjukkan bahwa pembelajaran daring pada anak berkebutuhan khusus berbeda dengan siswa reguler, karena anak berkebutuhan khusus memiliki kemampuan yang berbeda-beda. Di SDN Mojorejo I Kota Batu telah menerapkan jurnal berbasis 
aktivitas yang dapat diterapkan untuk anak berkebutuhan khusus. Pembelajaran daring tersebut memerlukan pendampingan khusus oleh orang tua, namun ketersediaan waktu orang tua yang terbatas dalam mendampingi anak berkebutuhan khusus mempengaruhi hubungan antara orang tua dan anak menjadi kurang dekat, selain itu juga mempengaruhi hasil dan makna belajar pada saat pembelajaran daring.

\section{DAFTAR PUSTAKA}

Alwasih, A. C. 2002. Pokoknya kualitatif : dasar-dasar merancang dan melakukan penelitian kualitatif. Pustaka Jaya

Amin, Barkatullah, 2015. Peran Orang Tua dalam Pendidikan Inklusif (Peran Orang Tua Anak Berkebutuhan Khusus dalam Konteks Sekolah Inklusi). Universitas Islam Negeri Sunan Kalijaga, Yogjakarta.

Bluth, K., \& Wahler, R. G. (2011). Does Effort Matter in Mindful Parenting? Mindfulness, 2(3), 175178. https://doi.org/10.1007/s12671011-0056-3

Covid19.go.id. (2020). Data Sebaran. Covid19.Go.Id. https://covid19.go.id/

Cahyani, Adinda, 2020. Peran Orang Tua dalam Membimbing Anak Selama Pembelajaran di Rumah sebagai Upaya Memutus Covid-19. Universitas Singaperbangsa Karawang.

Darmono, Al, 2015. Peran Orang Tua dalam Pendidikan Anak Berkebutuhan Khusus. Institut Agama Islam Ngawi.

Hawett dan Frenk D, 1968. The Emotionally Child in The
Classroom Disorder. Ellyn and Bacon. Inc. USA

Ilahi, Mohammad Takdir, 2013. Pendidikan Inklusi Konssep dan Aplikasi. Ar-Ruzz. Yogyakarta

Kurniawati, Euis, 2020. Analisis Peran Orang Tua dalam Mendampingi Anak di Masa Pandemi Covid-19. Universitas Pendidikan Indonesia, Bandung.

Kementerian Pendidikan Surat Edaran nomor 36962/MPK.A/HK/2020. Tentang Pelaksanaan Pembelajaran Daring.

Keputusan Presiden (Keppres) Nomor 11 Tahun 2020. Tentang Pembatasan Sosial Berskala Besar

Murtiningsih, D, 2013. Perang Orang Tua dalam Kegiatan Bermain Anak Usia Dini (

Pertiwi, Jamilah Candra 2015. Sekolah Inklusi untuk Anak Berkebutuhan Khusus : Tanggapan terhadap Kedepannya. Universitas Sebelas Maret Surakarta

Prabhawani, S. W. (2016). Pelibatan Orang Tua Dalam Program Sekolah Di Tk Khalifa Wirobrajan Yogyakarta. Pendidikan Guru PAUD S-1.

Sugiyono. 2011. Metode Penelitian Kuantitatif Kualitatif. Alfabeta. Bandung

Tarmansyah, 2009. Perspektif Pendidikan Inklusi : Pendidikan untuk Semua. Universitas Negeri Padang Press.

Undang-Undang No. 20 Tahun 2003. Tentang Pendidikan Inklusi.

Undang-Undang Dasar 1945 BAB VI Pasal 2, 3 dan 4. Tentang Anak Berkebutuhan Khusus dan Pendidikan Layanan Khusus. 


\section{WAWANCARA}

$\mathrm{Bu}$ Rini, Guru Pembimbing Khusus anak berkebutuhan khusus di Sekolah Inklusi SDN Mojorejo I Kota Batu wawancara oleh Saraswati Arsani 13 Januari 2021

$\mathrm{Bu}$ Fanisa, Orang tua Alif wawancara oleh Saraswati Arsani 14 Januari 2021
$\mathrm{Bu}$ Leona, Orang tua Zian wawancara oleh Saraswati Arsani 15 Januari 2021

$\mathrm{Bu}$ Sangadah, Orang tua Radit wawancara oleh Saraswati Arsani 18 Januari 2021 